\title{
Aluminum mobility in mildly acidic mine drainage: Interactions between hydrobasaluminite, silica and trace metals from the nano to the meso-scale
}

\author{
Manuel A. Caraballo ${ }^{\mathrm{a}, \mathrm{b}, \mathrm{c}, *}$, Richard B. Wanty ${ }^{\mathrm{d}}$, Philip L. Verplanck ${ }^{\mathrm{d}}$, \\ Leonardo Navarro-Valdivia ${ }^{\mathrm{b}, \mathrm{e}}$, Carlos Ayora ${ }^{\mathrm{f}}$, Michael F. Hochella $\mathrm{Jr}^{\mathrm{c}}$ \\ a Mining Engineering Department, University of Chile, Avda. Tupper 2069, 8370451 Santiago, Chile \\ ${ }^{\mathrm{b}}$ Advanced Mining Technology Center, University of Chile, Avda. Tupper 2007, 8370451 Santiago, Chile \\ ${ }^{c}$ Department of Geosciences, Virginia Tech, Blacksburg, Virginia 24061, USA \\ ${ }^{\mathrm{d}}$ US Geological Survey, Denver Federal Center, Denver, CO 80225, USA \\ ${ }^{\mathrm{e}}$ Department of Geology, University of Chile, FCFM, Plaza Ercilla 803, Santiago, Chile \\ ${ }^{\mathrm{f}}$ Institute of Environmental Assessment and Water Research, IDAA - CSIC, Jordi Girona 18, 08034 Barcelona, Spain
}

\section{A R T I C L E I N F O}

Editor: K Johannesson

Keywords:

Hydrobasaluminite nanoparticles

Aluminum and metals mobility

Acid rock drainage

Nanomineral

Banded aluminum and iron formations

\begin{abstract}
A B S T R A C T
Aluminum precipitates control the hydrochemistry and mineralogy of a broad variety of environments on Earth (e.g., acid mine drainage, AMD, coastal wetlands, boreal and alpine streams, tropical acid sulfate soils, laterites and bauxites, ...). However, the geochemical and mineralogical processes controlling $\mathrm{Al}$ (and other associated metals and metalloids) transport and removal in those environments are not fully understood. The geochemical system of Paradise Portal (Colorado, USA) comprises sulfate-rich mildly acidic waters, the hydrochemistry of which is directly controlled by the massive precipitation of hydrobasaluminite $\mathrm{Al}_{4}\left(\mathrm{SO}_{4}\right)(\mathrm{OH})_{10} \cdot 12-36 \mathrm{H}_{2} \mathrm{O}$. $\mathrm{Three}^{-1}$ connected but discernible aluminum precipitation stages were identified and described: 1) nanoparticle formation and size decrease along the creek, 2) hydrobasaluminite neoformation on the riverbed, and 3) precipitate accretion and accumulation on the riverbed leading to $\mathrm{Al}$ and $\mathrm{Fe}$ banded formations. The co-occurrence of $\mathrm{Al}$ and $\mathrm{Si}$ in the system was observed, recording significant amounts of Si accompanying the three different components of the system (i.e., nanoparticles and fresh and aged Al-precipitates). Also, abrupt and minor changes in the sedimentary record were described and proposed to be the response of the system to seasonal and interannual changes in AMD chemistry. Concerning the mobility of other metals and metalloids, P, Th, V, W, Ti and B showed a tendency to be preferentially incorporated into hydrobasaluminite, while others like Be, As, Se or Ba tend to remain dissolved in the water.
\end{abstract}

\section{Introduction}

The last three decades have seen the appearance of abundant scientific literature demonstrating the control exerted by sulfate-rich acid waters in both iron and aluminum cycles on Earth (Bigham and Nordstrom, 2000 and references therein) and Mars surface environments (Farrand et al., 2009; Ehlmann et al., 2016). Acid rock drainage (ARD) results from the interaction between water, sulfide minerals (mainly pyrite), oxygen and bacteria, resulting in low water $\mathrm{pH}$ and high concentrations of metals and sulfate (Bigham et al., 1996). The hydrochemistry of ARD waters on Earth's surface is frequently controlled by $\mathrm{Fe}(\mathrm{III})$ dissolution/precipitation. As a result, a myriad of studies have advanced the knowledge of the iron cycle, from water chemistry (Gammons et al., 2015; McKnight and Duren, 2004) to the minerals involved (Bigham and Nordstrom, 2000; Caraballo et al.,
2013), the role of microbes (Heinzel et al., 2009; Weber et al., 2006) and water suspended nanoparticles (Johnson et al., 2014), and coprecipitation or adsorption of other metals (Webster et al., 1998; Majzlan, 2011). However, the awareness of the crucial role played by aluminum in sulfate-rich acid waters is still growing as new Al-controlled natural and anthropogenic systems are described.

In this respect, the geochemistry of aluminum has been shown to control the compositional evolution of a broad variety of environments, such as acid mine drainage (AMD, Bigham and Nordstrom, 2000), mine pit lakes (Sánchez-España et al., 2016, 2018), coastal wetlands (Jones et al., 2011), boreal (Cory et al., 2006) and alpine (Munk et al., 2002) streams, tropical acid sulfate soils (Hicks et al., 2009), laterites and bauxites (Brown Jr. and Calas, 2011) or aquifers affected by acid atmospheric deposition (Lükewille and Van Breemen, 1991). In addition, these precipitates play an essential role in the evolution and

\footnotetext{
* Corresponding author at: Mining Engineering Department, University of Chile, Avda. Tupper 2069, 8370451 Santiago, Chile.

E-mail address: mcaraballo@ing.uchile.cl (M.A. Caraballo).
} 
performance of many passive treatment systems dealing with AMD remediation (Caraballo et al., 2011a, 2011b; Macías et al., 2012; Ayora et al., 2013, 2016). Moreover, aluminum sulfate can be considered by far the most used coagulation chemical in the purification of drinking waters (Väänänen et al., 2012). During the last decade, research has focused on the study of aluminum $\varepsilon$-Keggin type polyoxocations in natural water samples (Furrer et al., 2002; Casey et al., 2009 and references therein) but only a very few recent works have studied the mineralogical nature and geochemical behavior of $\mathrm{Al}^{3+}-\mathrm{SO}_{4}{ }^{2-}$-rich precipitates (Jones et al., 2011; Sánchez-España et al., 2011, 2016, 2018; Carrero et al., 2015). In this respect, the nanomineral hydrobasaluminite $\left(\mathrm{Al}_{4}\left(\mathrm{SO}_{4}\right)(\mathrm{OH})_{10} \cdot 12-36 \mathrm{H}_{2} \mathrm{O}\right)$ is probably the most frequent $\mathrm{Al}-\mathrm{SO}_{4}{ }^{2-}$-rich precipitate described in sulfate-rich acidic waters (Bigham and Nordstrom, 2000). It is important to note that hydrobasaluminite is a metastable, almost amorphous phase that dehydrates and irreversibly re-crystallizes to poorly crystalline basaluminite $\left(\mathrm{Al}_{4}\left(\mathrm{SO}_{4}\right)(\mathrm{OH})_{10} \cdot 5 \mathrm{H}_{2} \mathrm{O}\right)$ in a few days under atmospheric conditions (Bigham and Nordstrom, 2000).

Metal(loid) scavenging by (hydro)basaluminite in sulfate-rich acidic waters is known to have a strong potential to sequester elements such as $\mathrm{Cu}$ and Si (Bigham and Nordstrom, 2000). Also, several neutralizing laboratory experiments have confirmed its high scavenging capacity for several metal(loids) such as As, Se, Co, $\mathrm{Ni}$, etc., under very different conditions like oxic/oxidizing (Sánchez-España et al., 2006) and anoxic/reducing environments (Carrero et al., 2015). On the other hand, a few field studies have reported the removal of rare earth elements (Gimeno et al., 2000; Verplanck et al., 2004) and metals (i.e., As, Cr, Ni, $\mathrm{Cd}, \mathrm{Zn}$ and $\mathrm{Pb}$; Wanner et al., 2018) in contaminated creeks.

It is also worth noting that, despite the recent remarkable increase in the study of the environmental behavior of nanominerals and mineral nanoparticles in general (see compilations and perspectives by, e.g., Hochella Jr et al., 2008; Barnard and Guo, 2012; Barrón and Torrent, 2013, Caraballo et al., 2015), the environmental role played by hydrobasaluminite nanoparticles in field waters is still unknown.

The present research has a dual objective: a) to describe the geochemical and mineralogical processes accounting for metals and metalloids transport and removal in sulfate-rich mildly-acidic waters controlled by aluminum sulfate precipitation; and b) to obtain a better understanding of the environmental geochemistry of $\mathrm{Al}$ in field mildly acidic waters and sediments. To this end, the archetypal $\mathrm{Al}^{3+}-\mathrm{SO}_{4}{ }^{2-}$ controlled waters of Paradise Portal (Colorado, USA) were used to study how aluminum and metal mobilities are affected by three different stages of hydrobasuliminite observed, namely: 1) suspended nanoparticles transported by the creek, 2) fresh precipitates on the riverbed, and 3) mineral accretion and aging in banded formations.

\section{Materials and methods}

\subsection{Field site description}

Paradise Portal (3245 m.a.s.l.), a collapsed adit to a hardrock mine, is located $1.5 \mathrm{~km} \mathrm{SE}$ of Ophir Pass along the Middle Fork of Mineral Creek in the western San Juan Mountains, Colorado, USA (kmz file is available in the Supporting information). The bedrock consists of a sequence of middle to late Tertiary lavas and pyroclastic rocks (Larsen and Cross, 1956), and the wasterock pile at Paradise Portal consists of pyritized and propylitically altered San Juan Tuff. Unfortunately, no history of production from the mine could be located, but the wasterock pile is relatively small suggesting that the mine had minimal output.

The studied alpine river system begins at the mine portal, with effluent discharging from the caved portal and cascading down a dump pile (lower-right inset in Fig. 1). This first section (samples PP1 and PP2) is characterized by the presence of $\mathrm{Al}-\mathrm{Fe}$ layered formations. At the foot of the dump pile the mine effluent encounters a small unnamed pristine alpine creek. The resulting water mixture flows west to east approximately $1.3 \mathrm{~km}$ to the tributary of another pristine alpine creek

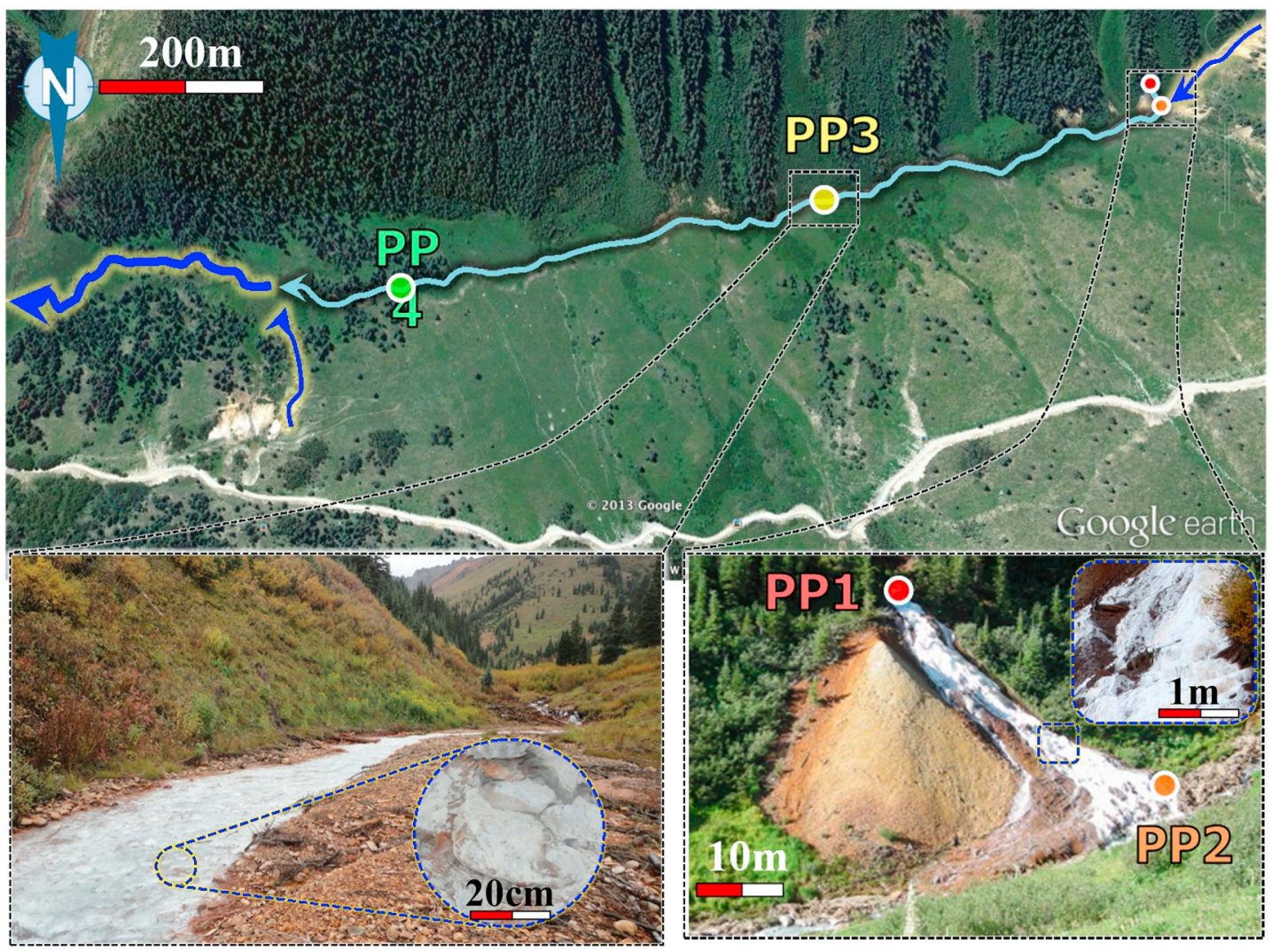

Fig. 1. Satellite view (top) and field pictures (bottom) of Paradise Portal riverine system. PP1, PP2, PP3 and PP4 mark the location of the sampling points. 
(Fig. 1). This second section is characterized by the presence of white precipitates coating the surface of the riverbed boulders (PP3 and PP4. (lower-left inset in Fig. 1). This riverbed white coating decreases progressively along the watercourse until it practically disappears a few hundred meters after PP4 (due to the AMD mixture with clean waters).

\subsection{Sampling and analyses of waters, nanoparticles and solids}

The sampling campaign took place in summer 2012 because the field site is consistently under snow cover from late Autumn to mid Spring. Three different water samples were collected at each sampling point, corresponding to unfiltered waters (raw waters) and waters filtered through $0.45 \mu \mathrm{m}$ and $0.1 \mu \mathrm{m}$ Millipore filters on Millipore syringe filter holders. All samples were acidified in the field to $\mathrm{pH}<1$ with Suprapur ${ }^{\circledast} \mathrm{HNO}_{3}$ and stored at $4{ }^{\circ} \mathrm{C}$ in $60 \mathrm{~mL}$ Nalgene ${ }^{\circledast}$ containers until analyzed.

Details about temperature, electrical conductivity, redox potential and $\mathrm{pH}$ field measurements can be found in the Supporting Information.

Major cations (Al, Ca, Fe, K, Mg, Mn, Na, P, S, Si, Sr, and Zn,) were measured by ICP-AES (Perkin-Elmer ${ }^{\circledR}$ Optima $3200 \mathrm{RL}$ ) and trace metals (As, B, Ba, Be, Cd, Co, Cr, Cs, Cu, Ga, Hf, Li, Ni, Pb, Rb, Sc, Se, Th, Ti, U, V, W, Y) with ICP-MS (Perkin-Elmer ${ }^{\circledR}$ SciexElan 6000). Details of the analytical procedures are described in the Supporting information.

Nanoparticles were sampled using transmission electron microscopy (TEM) grids (lacey carbon on 400 mesh gold, Electron Microscopy Sciences). Environmental Scanning electron microscopy (ESEM) Quanta 600 FEG SEM, FEI, Hillsboro, OR, USA) was first used to survey the TEM grids to note approximate particle size, morphology and element composition. A JEOL 2100 TEM instrument was used for further morphological and element characterization of the nanoparticles. The observed nanoparticles (hydrated aluminum sulfates) were very sensitive to the electron beam and the exposure time before the nanoparticles began to "melt down" was too short (a few seconds) to perform detailed crystallographic studies or to obtain images at high magnifications. To avoid these limitations and to obtain some useful information, it was decided to use the equipment on scanning mode (STEM) to generate compositional maps. Although, magnification and resolution of the obtained images are low, this approach allows differentiatiation of the limits between different minerals by the delimitation of areas with different chemical composition in the chemical maps. Details of the nanoparticle sampling and analytical procedures are offered in the Supporting information.

Two different types of solid samples were obtained, corresponding to: a) smooth, creamy and white surficial coatings of aluminum precipitates and b) brittle $\mathrm{Al}-\mathrm{Fe}$ layered crust armoring the rocks of the riverbed. All the samples were stored in $60 \mathrm{~mL}$ Nalgene ${ }^{\circledast}$ containers for transport and dried in the lab using silica gel desiccant at room temperature.

X-ray diffraction (XRD) analyses of selected samples were performed using a Bruker D5005 X-ray diffractometer with $\mathrm{Cu}$ Ka radiation. Diffractometer settings were: $40 \mathrm{kV}, 30 \mathrm{~mA}$, and a scan range of $2-65^{\circ} 2 \theta, 0.05^{\circ} 2 \theta$ step size, and 20 s counting time per step.

Seeking to know the bulk chemistry of the $\mathrm{Al}$ and Fe neoformed mineral phases, solid samples were analyzed by ICP-AES and ICP-MS after digesting them with concentrated $\mathrm{HNO}_{3}$ at room temperature. Notice that this type of partial digestion (although it is enough to dissolved the typical precipitates in AMD affected waters) will not dissolve most silicates and other resistant minerals. The analytical conditions were the same used for the analysis of the water samples.

Carbon-coated polished sections were studied with a JEOL JXA8200 SuperProbe electron probe micro-analyzer (EPMA), using the fitted wavelength-dispersive spectroscopy (WDS) equipment to obtain quantitative chemical analysis. More details on the analytical conditions can be found in the Supporting Information.

\subsection{Geochemical modeling}

Water speciation and mineral saturation indexes were calculated with PHREEQC code, version 3.4 (Parkhurst and Appelo, 2013). Thermodynamic data for minerals were obtained from the WATEQ4f database (Ball and Nordstrom, 1991) and LNLL database (Johnson et al., 1992), except for hydrobasaluminite (Sánchez-España et al., 2011) and schwertmannite (Caraballo et al., 2013). The PHREEQC code was run using each thermodynamic database separately and the results of both approaches were compared. These two different databases were used to complement each other (all the elements under study are not included in a single database) as well as to compare the different species predicted by each of them.

\section{Results}

\subsection{Water chemistry}

The water emerging from Paradise Portal will be considered the initial water undergoing several physical and geochemical processes and transformations (e.g., water mixing and mineral precipitation). Despite the evident field observation of white precipitates on the riverbed, major and minor dissolved elements at PP1 and PP2 do not show any substantial difference (Fig. 2). The first significant change in the water chemistry of the system is due to the mixture of the AMD at PP2 and a pristine alpine creek coming from a nearby rock glacier.

The water samples from the present study can be classified as mildly acid ( $\mathrm{pH}=5.05$ to 5.5), calcium sulfate waters with moderate metal contents (Fig. 2a and b). Water $\mathrm{pH}$ is buffered by hydrobasaluminite precipitation according to the following equation (Sánchez-España et al., 2011):

$$
\begin{aligned}
4 \mathrm{Al}^{3+}{ }_{(\mathrm{aq})}+\mathrm{SO}_{4}{ }^{2-}{ }_{(\mathrm{aq})}+22- & 46 \mathrm{H}_{2} \mathrm{O}_{(\mathrm{l})}=\mathrm{Al}_{4}\left(\mathrm{SO}_{4}\right)(\mathrm{OH})_{10} \cdot 12-36 \mathrm{H}_{2} \mathrm{O}_{(\mathrm{s})} \\
+ & 10 \mathrm{H}^{+}{ }_{(\mathrm{aq})}
\end{aligned}
$$

As a result, water electrical conductivity decreased from 2.22 to $1.07 \mathrm{mS} / \mathrm{cm}$ and water pH slightly increased from 5.12 to 5.5 (Fig. 2a). This water mixture also drastically reduced the concentrations of dissolved elements (Fig. 2). Some minor elements even became undetectable (i.e., below detection limit, Table A1) by the mass spectrometric analytical technique employed. Mass balance calculations (using PP2 and PP3 water samples) of some selected elements were made to evaluate the dilution effect of the pristine alpine creek on the mine effluent. Assuming that the pristine creek does not contain any Mn, Zn or Ni (common components of ARD waters), a 3 to 1 ratio was obtained. In other words, the pristine alpine creek had a flow rate three times higher than the mine effluent. This calculation is in agreement with the field estimations of flow rate.

At distances of 500 and $1000 \mathrm{~m}$ downstream from the water mixture (PP3 and PP4, respectively), the water chemistry showed a stable pattern with almost the same chemical composition in both sampling points and a very slight $\mathrm{pH}$ decrease (from 5.50 to 5.36). Nevertheless, a continuous layer of white precipitates could be observed armoring the surface of the riverbed (lower-left inset in Fig. 1).

Despite the elevated Fe concentration, the water hydrochemistry is primarily controlled by aluminum precipitation because the outflowing groundwater has a low Eh (consequently, most of the Fe must be in the form of ferrous species like $\mathrm{Fe}^{2+}$ and $\mathrm{FeSO}_{4}$ while a minimal proportion is forming ferric species like $\mathrm{Fe}(\mathrm{OH})_{2}{ }^{+}$, Appendix A) and water $\mathrm{pH}$ is already 5 (suitable for aluminous mineral phases like hydrobasaluminite to precipitate). This hydrochemical behavior has been previously reported within AMD passive treatment systems (Caraballo et al., 2011a, 2011b) where a ferrous AMD flowed through an alkaline reagent increasing its $\mathrm{pH}$ and precipitating hydrobasaluminite but no Fe-precipitates. 
(a)

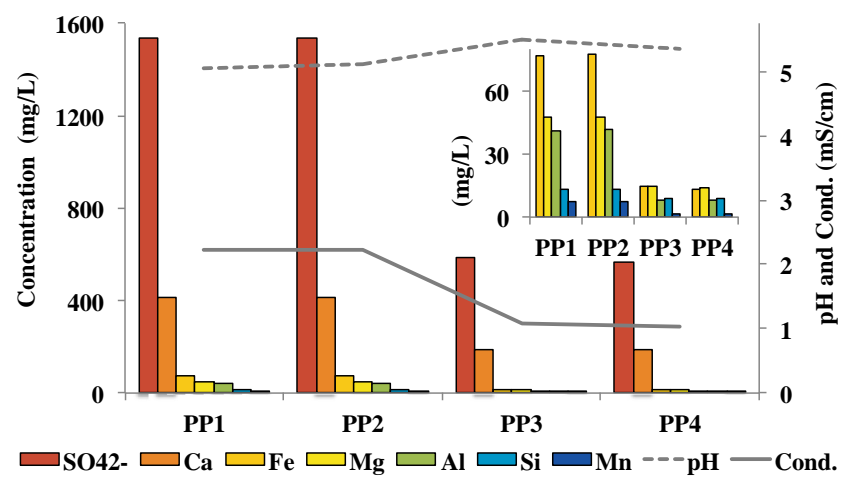

(b)

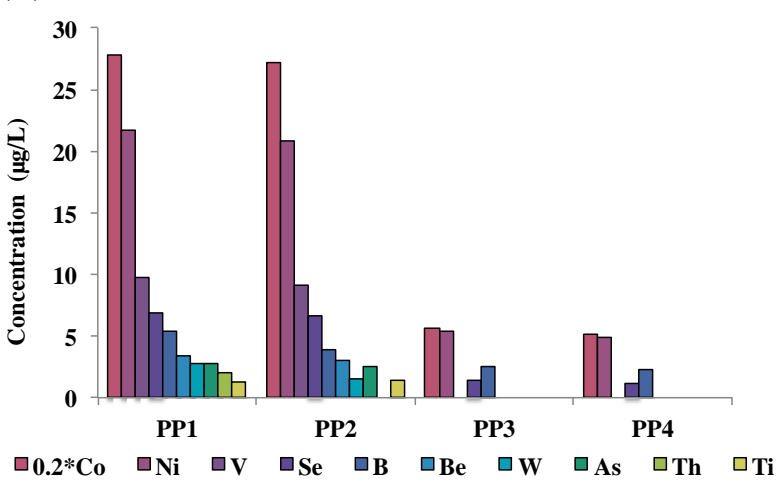

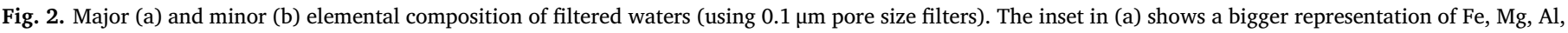
$\mathrm{Si}$, and $\mathrm{Mn}$ concentrations to facilitate their reading.

\subsection{Suspended particles characterization}

Despite the apparent lack of change in water chemistry before and after the confluence of the Paradise Portal effluent and the alpine creek (Fig. 2), field observation of suspended particles in the water (i.e., slight white turbidity) suggested the presence of another component in the Paradise Portal stream system. Fig. 3 shows the concentration of some selected elements present in raw (unfiltered), 0.45 (filtered using $0.45 \mu \mathrm{m}$ pore size filters) and 0.1 (filtered using $0.1 \mu \mathrm{m}$ pore size filters) waters. For the sake of clarity and to avoid any redundancy, only the results from PP1 and PP3 are used in this discussion (PP1 and PP2 results and PP3 and PP4 results are almost equal to each other, respectively). Complete information may be found in the supporting material (Table A1). As can be observed in Fig. 3, most major and minor elements show virtually the same concentration in raw, 0.45 and 0.1 water samples.

Nevertheless, a clearly discernible difference is observed between $\mathrm{Al}$ concentrations in unfiltered (raw) and filtered ( 0.45 and 0.1$)$ waters. As previously stated, water $\mathrm{pH}$ is buffered by hydrobasaluminite $\left(\mathrm{Al}_{4}\left(\mathrm{SO}_{4}\right)\right.$

(a)

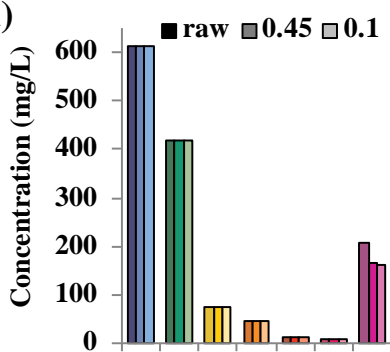

(b)

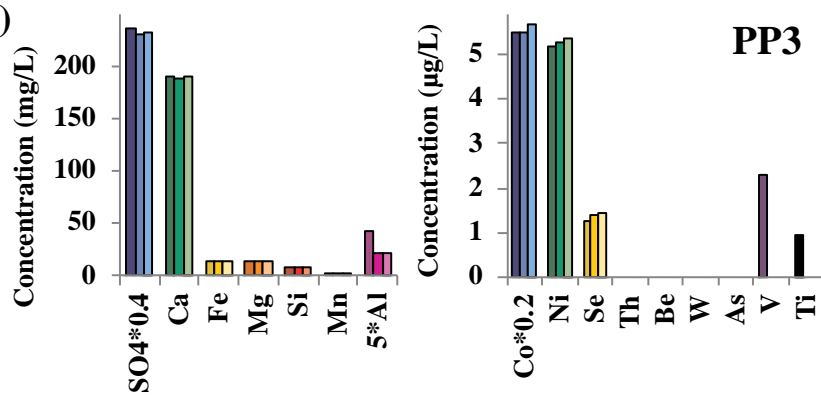

Fig. 3. Comparison of some selected major and minor elements in raw (unfiltered, dark colors), 0.45 (filtered using $0.45 \mu \mathrm{m}$ pore size filters, medium-dark colors) and 0.1 (filtered using $0.1 \mu \mathrm{m}$ pore size filters, light colors) waters at PP1 (a) and PP3 (b). Notice that some original concentrations have been modified to fit the great variety of data in one graphic (i.e., $\mathrm{SO}_{4}{ }^{2-*} 0.4 ; \mathrm{Al}^{*} 5$ and $\mathrm{Co}^{*} 0.2$ ).
$\left.(\mathrm{OH})_{10} \cdot 12-36 \mathrm{H}_{2} \mathrm{O}\right)$ precipitation. Therefore, both the formation of suspended Al-rich minerals and the concomitant coprecipitation and removal of other elements with a similar chemical behavior could be expected (in addition to the adsorption of other elements).

Regarding the incorporation of other elements in the suspended particles, only $\mathrm{V}$ and $\mathrm{Ti}$ showed substantial differences in their unfiltered and filtered water concentrations (Fig. 3). This behavior may be explained using the chemical speciation of the elements in the water (as calculated by PHREEQC) and considering the concept of ionic potential (IP, ion charge/ion radius, Railsback, 2003). In the studied waters, Ti is present as $\mathrm{Ti}^{4+}(\mathrm{IP}=6.7)$ in the form of $\mathrm{Ti}(\mathrm{OH})_{4}$ (Appendix B). Its IP is very close to that of $\mathrm{Al}^{3+}(\mathrm{IP}=6)$, therefore a similar aqueous behavior could be anticipated. $\mathrm{V}$ total concentration is $99.5 \%$ made of $\mathrm{V}^{5+}$ $(\mathrm{IP}=8.47)$ species (i.e., $\mathrm{VO}_{2}(\mathrm{OH})^{-}, \mathrm{H}_{2} \mathrm{VO}_{4}{ }^{-}, \quad \mathrm{VO}(\mathrm{OH})_{3}$ and $\mathrm{VO}_{3} \mathrm{OH}^{-2}$ ). On the other hand, elements like Se, Th, Be, W, and As (depending on their specific chemical speciation) may or may not show a similar aqueous behavior to $\mathrm{Al}^{3+}$. The case of As exemplifies the behavior shown by these elements in the waters of the present study (Fig. 3). Under the measured $\mathrm{pH}$ and pe conditions, $\sim 99 \%$ of As is present as $\mathrm{As}^{5+}(\mathrm{IP}=10.8)$ while almost no $\mathrm{As}^{3+}(\mathrm{IP}=5.2)$ is predicted by the geochemical model (Appendices A and B). Hence, the big difference in $\mathrm{Al}^{3+}$ and $\mathrm{As}^{5+}$ IP values suggests a very dissimilar aqueous behavior for those two elements. This deduction is in agreement with the field data where total As concentrations (contrary to $\mathrm{Al}$ concentrations) did not show any difference between unfiltered or filtered samples (Fig. 3).

Neither of the filtered samples at PP3 (or at PP4) have detectable dissolved $\mathrm{Ti}$ or $\mathrm{V}$, but these two metals were detected in the unfiltered sample. Therefore, it is reasonable to assume that the Al-rich suspended particles are sinks for these (and probably to a lesser extent other) metals.

To better characterize the nature and size of the suspended particles, different samples from each sampling point were studied by TEM. A common property of the suspended particles in the Paradise Portal system is that they are complex micrometer-size particles (ranging approx. From 1 to $10 \mu \mathrm{m}$ for the longest axis) comprising a network of spherical aluminum sulfate nanoparticles and an amorphous Si-rich matrix Fig. 4).

Regarding the size distribution of the Al-rich nanoparticles, differences were observed between samples before (PP1 and PP2) and after (PP3 and PP4) the mixture between the mine effluent and the alpine creek at the foot of the wasterock pile. Before the confluence, the spherical nanoparticles had a mean size close to $100 \mathrm{~nm}$ (PP1 and PP2 in Table 1). After the confluence (and the subsequent decrease of metal load in the resulting water) the mean nanoparticle size decreased by $50 \%$ or more (PP3 and PP4 in Table 1). In addition, the shape of the nanoparticles also changed from fairly spherical and with easily 

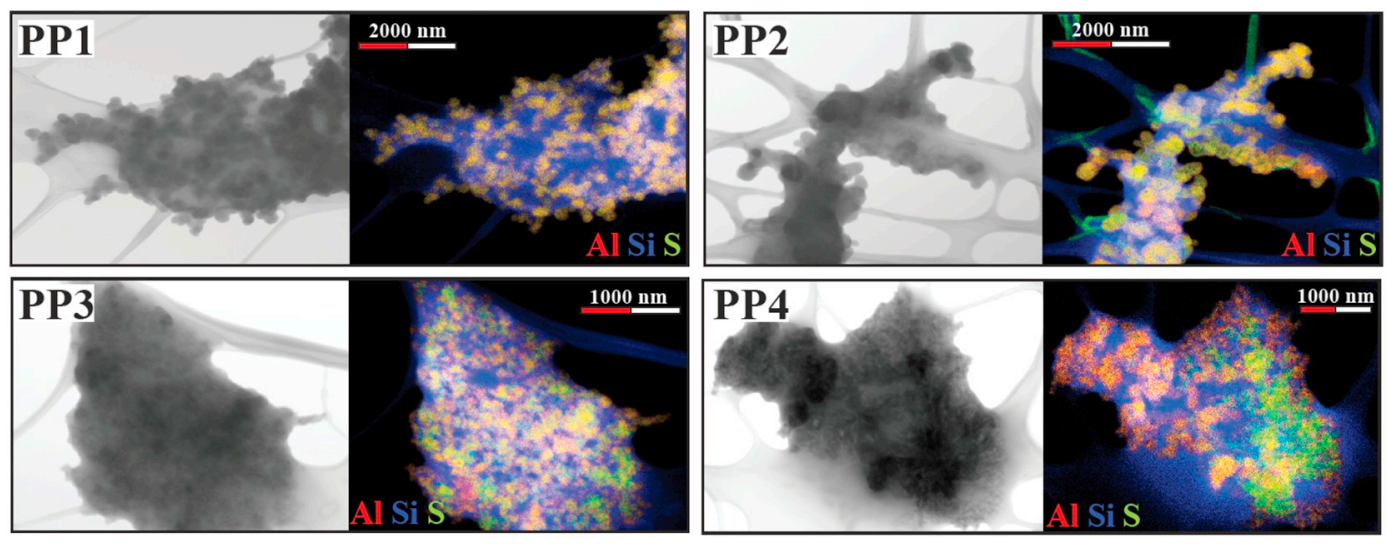

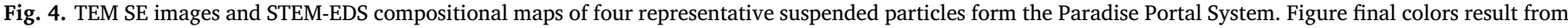

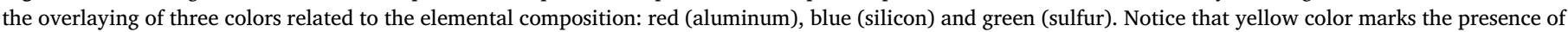

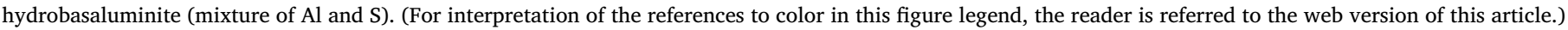

Table 1

Water suspended nanoparticles size distribution measured by TEM.

\begin{tabular}{lccc}
\hline Sample & $\mathrm{n}^{\circ}$ measurements & Mean (nm) & SD (nm) \\
\hline PPP1 & 199 & 94 & 33 \\
PPP2 & 131 & 102 & 21 \\
PPP3 & 204 & 42 & 10 \\
PPP4 & 177 & 55 & 15 \\
\hline
\end{tabular}

SD: standard deviation

recognizable limits in PP1 and PP2 to nanoparticles with an undefined shape and no easily recognizable limits in PP3 and PP4. To the best of our knowledge, this is the first time that a particle size reduction effect by water dilution has been reported in an acidic stream system.

Unequivocal mineral characterization of the nanoparticles by TEM was impossible because of their extremely poor crystallinity (they behave as an amorphous material under electron diffraction) and because they were very sensitive to the electron beam (the exposure time before the nanoparticles began to "melt down" was too short to perform detailed crystallographic studies). However, a) the oversaturation shown by hydrobasaluminite in the geochemical model, (Fig. A3), b) the observation of $\mathrm{Al}$ and $\mathrm{S}$ as the two main constituents of the nanoparticles (Table A2) and c) the confirmation that hydrobasaluminite is the sole aluminum mineral phase identified in the fresh precipitates on the riverbed (discussed in detail in the next section), enable to assume that hydrobasaluminite is the most likely mineral phase forming the nanoparticles.

\subsection{Neoformed precipitates on the riverbed}

The Paradise Portal System can be divided into two distinct sectors: the watercourse over the mine wasterock pile and the watercourse over a riverbed composed of cemented pebbles and cobbles (Fig. 1). Both sections have a smooth, creamy white surficial coating of aluminum precipitates underlain by a brittle $\mathrm{Al}-\mathrm{Fe}$ layered crust cementing the rocks of the riverbed. The thickness of both fresh and layered precipitates is the same between PP1 and PP2, increases from PP2 to PP3, decreases from PP3 to PP4 and there are almost no precipitates coating the riverbed after PP4.

Hydrobasaluminite was confirmed (by XRD) as the sole slightly crystalline Al-bearing mineral in the fresh precipitates on the surface of the riverbed (Fig. A5). Further, $\mathrm{Al}$ and $\mathrm{S}$ are the two main components of those precipitates showing $\mathrm{Al} / \mathrm{S}_{\text {molar }}$ ratios very close to the theoretical stoichiometric value of 4 (Table A2). In general, it is also observed that the third major component is Si followed by $\mathrm{P}$.

Distribution coefficients were calculated to quantify element preferences for the liquid or solid phase during hydrobasaluminite precipitation:

$D_{m-w}=\frac{([t] /[d])_{\text {mineral }}}{([t] /[d])_{\text {water }}}$

where [t] is the concentration of the trace element under study and [d] is the concentration of the dominant element (i.e., $\mathrm{Al}$ ).

As seen in Fig. 5, at PP1 and PP2, P, Th, V, W, Ti and B show a general tendency to be incorporated into hydrobasaluminite, while others like Be, As, Se and Ba tend to remain dissolved in the water.

A detailed examination of the results reveals differences in hydrobasaluminite composition between PP1-PP2 and PP3 (Fig. A6, Table A2); namely: a) $\mathrm{Al}$ total concentration and $\mathrm{Al} / \mathrm{S}_{\text {molar }}$ ratio is higher in PP3, b) Si content is significantly lower in PP3, and c) the results of the few distribution coefficients that were generated at PP3 are systematically $<1$ (i.e., trace elements remain in solution).

\subsection{Banded Al- and Fe-rich formations}

As previously indicated, Al- and Fe-rich layered precipitates coat the rocks of the Paradise Portal system from PP1 to a few hundred meters after PP3. A sample from the vicinity of PP3 (where the layered precipitates are thicker) was selected (Fig. A7D). These layered precipitates show great complexity and heterogeneity in size, texture and color. Thus, it is difficult to obtain an archetypal section of the sequence of precipitation. Having this limitation in mind and to offer some insight into the general geochemical composition of those precipitates, three well-differentiated layers were sampled and analyzed (Fig. 6 and Table S2), viz.: Fe-L (Fe-rich layer), Al-L1 (Al-rich layer 1) and Al-L2 (Al-rich

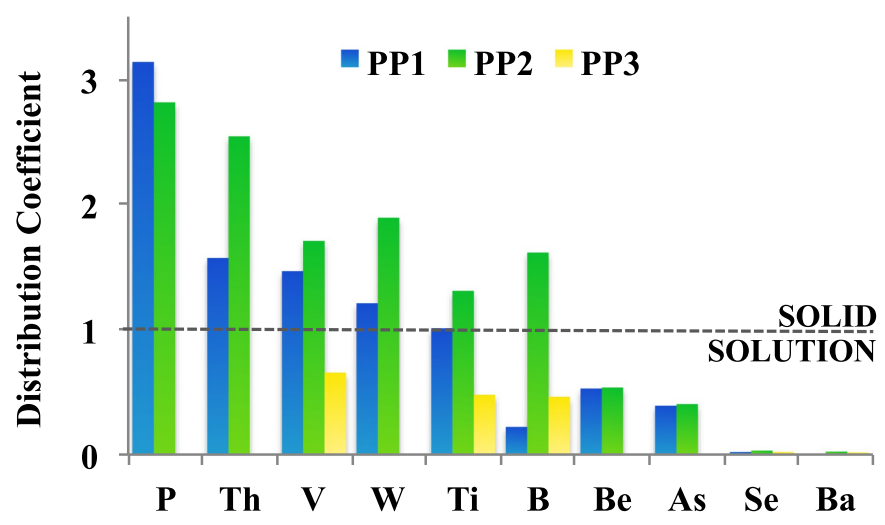

Fig. 5. Trace element distribution coefficients between the AMD and freshly precipitated hydrobasaluminite on the riverbed. Notice that. 

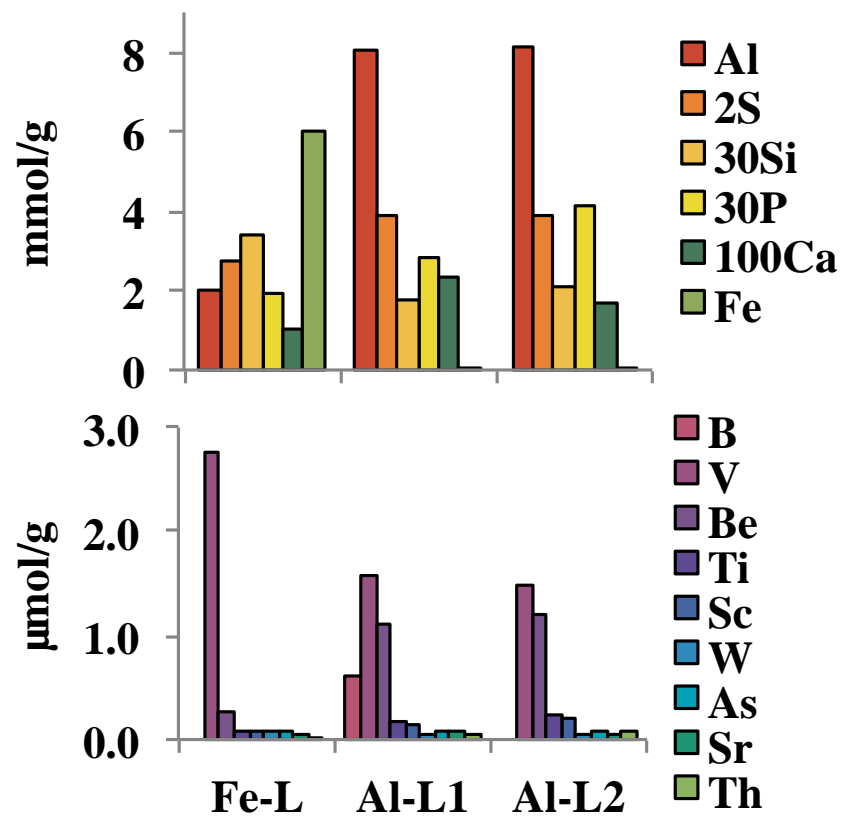

Fig. 6. Bulk chemical composition of aged $\mathrm{Al}-\mathrm{Fe}$ banded boulder coatings in the proximities of PP3. Fe-L $=$ Fe rich layer; Al-11 and Al-L2 = Al-rich layers.

layer 2). Special care was taken to ensure that the samples correspond to a temporal sequence (Fe- $\mathrm{L}$ is the uppermost and newest layer while $\mathrm{Al}-\mathrm{L} 2$ is the lowermost and oldest layer).

The Fe-rich layer contained mainly $\mathrm{Fe}, \mathrm{Al}$ and $\mathrm{S}$ (Fig. 6) and had Fe/ $\mathrm{S}_{\text {molar }}$ and $\mathrm{Al} / \mathrm{Fe}_{\text {molar }}$ ratios of 4.43 and 0.3 , respectively (Table A2). Although no conclusive results about the specific mineralogy of these precipitates were generated, the observed $\mathrm{Fe} / \mathrm{S}$ molar ratio and the chemical composition of the waters are consistent with what would be found for Al-rich schwertmannite or a mixture of schwertmannite $\left(\mathrm{Fe}_{8} \mathrm{O}_{8}(\mathrm{OH})_{8-2 x}\left(\mathrm{SO}_{4}\right)_{x}\right.$, with $\left.0.75>x>2.58\right)$ and other Al-phases as the most probable constituents. Notwithstanding the specific mineralogy, metal scavenging by the Fe-rich layer is mostly limited to $\mathrm{V}$ (Fig. 6).

The Al-rich layers (Al-L1 and Al-L2) exhibit a similar composition with $\mathrm{Al} / \mathrm{S}_{\text {molar }}$ ratios of 4.1 and 4.2 , respectively (Table A2). They also have a great compositional resemblance with the fresh precipitates generated in the river (PP3, Fig. A6 and Table A2). The only significant difference between the aged and the fresh precipitates in PP3 is the higher content of B in the former and the slightly higher concentration of $\mathrm{V}$ in the latter. Based on these $\mathrm{Al} / \mathrm{S}$ molar ratios and the demonstrated presence of hydrobasaluminite in the fresh precipitates, the most plausible candidate to form the aged layered precipitates is probably also hydrobasaluminite.

The observed cm-scale alternation of $\mathrm{Al}$ and $\mathrm{Fe}$ layers can be interpreted as recorded evidence of major temporal changes in the hydrochemistry of the Paradise Portal system. However, more subtle differences within layers are expected at the $\mu \mathrm{m}$ scale. To check this hypothesis, different selected sections of the layered precipitates in PP3 were studied under the EPMA-WDS. The main observations are summarized in the compositional maps shown in Fig. 7. If only Al, Fe and S compositional maps are taken into account, the $0.5 \times 0.75 \mathrm{~mm}$ section can be divided in two fairly homogeneous Al-rich regions separated by a Fe-rich strip. This lamination could be interpreted as the result of three singular hydrochemical events. However, a very different interpretation can be reached if Si and P compositional maps are considered. The opposite compositional variations shown by these two elements suggest that multiple minor hydrochemical events occurred within the three major events recorded by $\mathrm{Al}, \mathrm{Fe}$ and $\mathrm{S}$ compositional variations.

A detailed point analysis of the sub-layers marked by $\mathrm{Si}$ and $\mathrm{P}$ reveals subtle but perceptible variations in the composition of all major components (Fig. 7 lower-right inset and Table A3). In addition, the Al/ $\mathrm{S}_{\text {molar }}$ ratio in all the sub-layers $(3.9 \pm 0.33)$ remains near the theoretical stoichiometric value of hydrobasaluminite $\left(\mathrm{Al}_{4}\left(\mathrm{SO}_{4}\right)(\mathrm{OH})_{10} \cdot 12\right.$ $36 \mathrm{H}_{2} \mathrm{O}$ ).

Please notice that the observed elemental fluctuation within the banded Al- and Fe-rich formation correspond to a section of the creek after the mixture with pristine waters. Therefore, the extrapolation of these results to other different sections of the creek (e.g., PP1 and PP2, before the mixture with pristine waters) or to other similar creeks should be made with great caution.

\section{Discussions}

\subsection{Al and Si interactions in AMD at mildly acidic $p H$ (5 to 5.5)}

Aluminum and silicon are typically among the most abundant metals and metalloids in acid mine drainage, only after Fe (Bigham and Nordstrom, 2000). Specifically, in Paradise Portal waters, Al and Si are the fifth and sixth major elements (Fig. 2). These two elements, (present in $\mathrm{AMD}$ as $\mathrm{Al}(\mathrm{OH})_{\mathrm{n}}{ }^{3-\mathrm{n}}$ or $\mathrm{Si}(\mathrm{OH})_{\mathrm{m}}{ }^{4-\mathrm{m}}$, where $\mathrm{n}$ is typically $0-3$ for $\mathrm{Al}$ and $\mathrm{m}=4$ for $\mathrm{Si}$, Appendix B) have very similar ionic radii $\left(\mathrm{Al}^{3+}=0.5 \AA\right.$ and $\mathrm{Si}^{4+}=0.41 \AA$ ) and charge. As a result, they may share a similar fate in many different Earth environments, as recorded by the abundance of many different aluminosilicates in the Earth's crust (in many of them $\mathrm{Al}^{3+}$ and $\mathrm{Si}^{4+}$ occupy the same crystallographic positions).

Previous studies have reported the presence of up to $2 \mathrm{wt} \%$ of $\mathrm{SiO}_{2}$ in hydrobasaluminite precipitates within the reactive material of a passive treatment system remediating AMD (Caraballo et al., 2011a). Furthermore, removals of almost $40 \mathrm{mg} / \mathrm{L}$ of $\mathrm{Si}$ from the treated AMD were obtained (Caraballo et al., 2011b). Recent studies by SánchezEspaña et al. (2016, 2018) have reported Si coprecipitation and adsorption during the abiotic and biotic precipitation of hydrobasaluminite in the anoxic deep strata of acidic pit lakes in the Iberian Pyrite Belt (SW, Spain). These studies observed abiotic sub-micron (200-900 nm) subrounded particles of hydrobasaluminite, usually coalescing into groups of several units (Sánchez-España et al., 2016). These hydrobasaluminite nanoparticles were formed at a $\mathrm{pH}$ of 4-4.5 and consistently showed homogeneous distributions of significant amounts of Si (spanning from 0.7 atom \% up to 6.5 atom \%, according to STEM-EDX analyses). Additionally, oxygenated Fe(III)-rich water from Cueva de la Mora acidic pit lake surface $(\mathrm{pH}$ 2.6) was neutralized under oxic conditions to study metal coprecipitation during hydrobasaluminite formation (Sánchez-España et al., 2016). Among all the elements removed from the solution, this experiment showed a Si removal by hydrobasaluminite of up to $25 \%$ at $\mathrm{pH} 6.0$.

Regarding the formation of sub-micron rounded particles of hydrobasaluminite coalescing into groups of several units, the present study observed similar structures in PP1 and PP2 (Fig. 4). However a very different interaction between $\mathrm{Al}$ and $\mathrm{Si}$ was observed. An ESEM backscattered electron image of a representative suspended particle from PP1 is shown in Fig. 8 a). As can be observed, this micrometer size particle comprises hundreds of coalescing hydrobasaluminite nanoparticles forming an intricate 3D structure with no apparent matrix between the nanoparticles. However, if the sample is studied using TEM the existence of a nanometric thin film around the nanoparticles is observed (Fig. 8b). This discrepancies are highlighted by yellow and green circles in both images, that highlight areas with or without matrix, respectively. In addition, the $\mathrm{Al}$, and $\mathrm{Si}$ elemental compositional maps obtained by EDS (Fig. 8b) clearly outline these two different situations, as well as the fact that the matrix is only made by $\mathrm{Si}$ and that almost no $\mathrm{Si}$ is incorporated into the hydrobasaluminite nanoparticles. The non-observation by ESEM of this Si-rich matrix and its observation by TEM allows to infer that it must have a thickness of a few tens of nanometers in the direction perpendicular to the electron beam that makes it invisible to ESEM. 

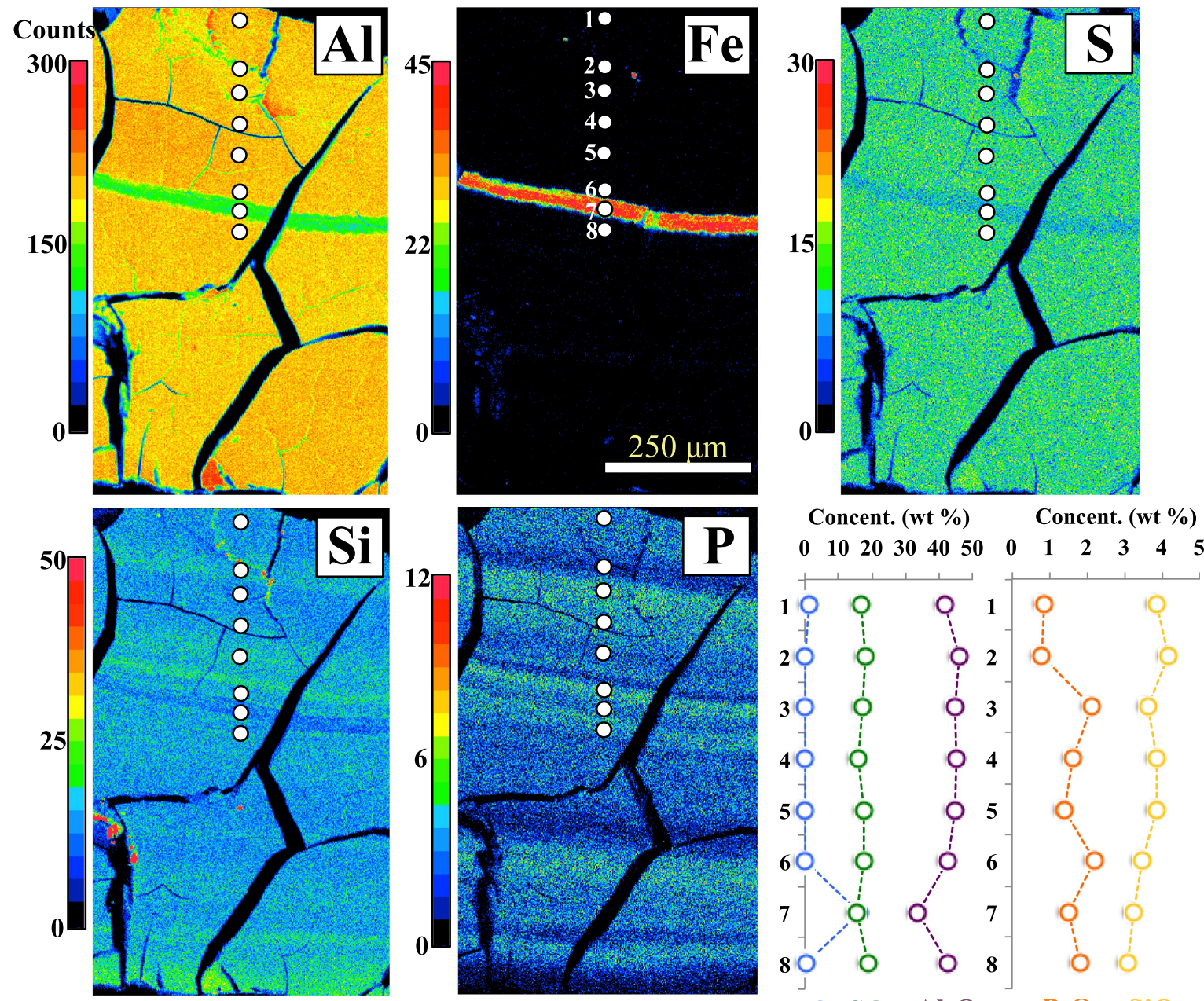

$\begin{array}{llllllllllll}0 & 10 & 20 & 30 & 40 & 50 & 0 & 1 & 2 & 3 & 4 & 5\end{array}$

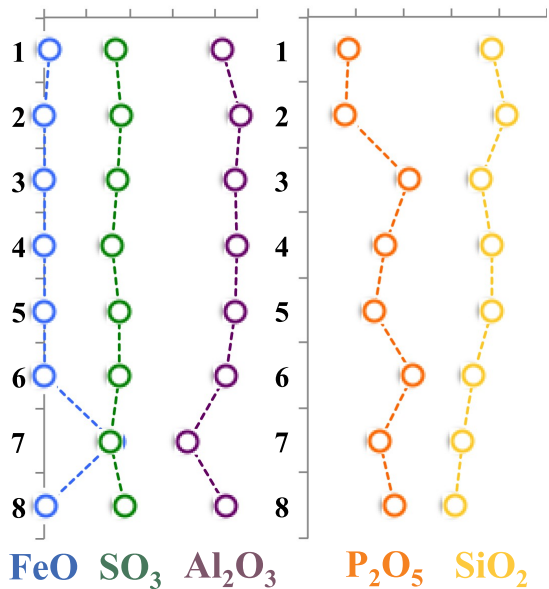

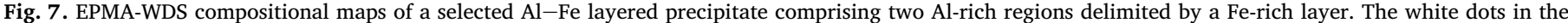

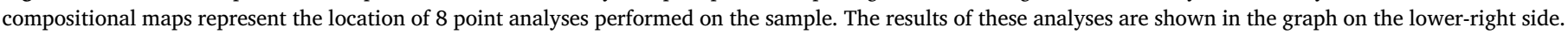

The existence of a nanometric Si-rich film growing on top of massive micrometer-size particles made of coalescing hydrobasaluminite nanoparticles (i.e., the amount of $\mathrm{Si}$ in the particles can be considered negligible or almost nonexistent compared with the amount of $\mathrm{Al}$ ) is in agreement with the field observations where only aqueous $\mathrm{Al}$ concentration exhibited a discernible difference between the filtered and unfiltered waters (Fig. 3).

According to the geochemical calculations using the Wateqf database (discrepancies in the results obtained using the Wateqf or the LLNL database are explained in Appendix A), calculations of saturation indexes confirmed the thermodynamic favorability of several $\mathrm{Al}$ and $\mathrm{Si}$ mineral phases (Fig. A3). Among them, hydrobasaluminite and chalcedony $\left(\mathrm{SiO}_{2}\right)$ are proposed as the most plausible candidates to form in the surficial oxic acidic sulfate-rich waters of the present study.

The surface chemistry of the coalescing hydrobasaluminite nanoparticles composing the micrometer-size aggregates is probably controlled by the nanometric Si-rich film growing on top. In other words, despite hydrobasaluminite being the main component of the aggregates, the surficial physical and chemical properties (e.g., piezoelectric point, sorption/desorption capacity, ...) shown by the particles a)

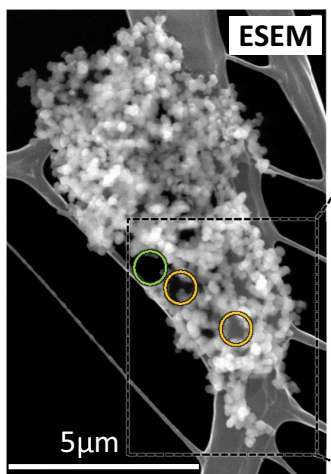

b)

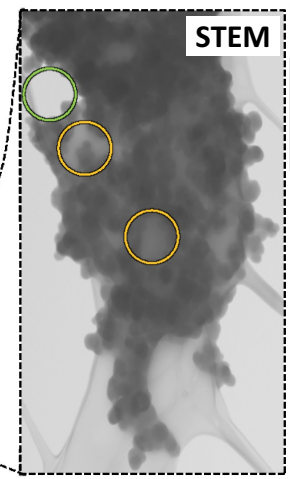

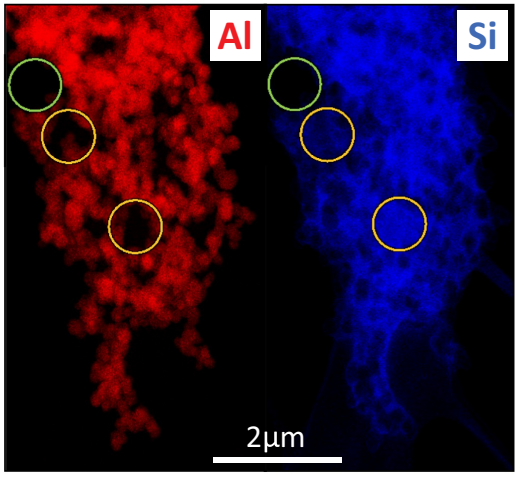

Fig. 8. a) ESEM backscattered electron image of a micrometer size particle from PP1 made by hundreds coalescing hydrobasaluminite nanoparticles, and b) STEM bright field image and EDS elemental compositional maps of a selected section in a). Yellow and green circles are used to highlight areas with or without matrix. (For interpretation of the references to color in this figure legend, the reader is referred to the web version of this article.) 
correspond to chalcedony (or other $\mathrm{SiO}_{2}$ mineral phase). However, it is clear that both hydrobasaluminite and some silica phase are forming spontaneously from solution, so the possibility that both surfaces are able to interact with the bulk solution cannot be ruled out.

It can also be observed that hydrobasaluminite fresh precipitates on the riverbed at PP1 and PP2 show $\mathrm{Al} / \mathrm{Si}_{\text {molar }}$ ratios of 19.1 and 25.6, respectively; whereas hydrobasaluminite at $\mathrm{PP} 3$ exhibits an $\mathrm{Al} / \mathrm{Si}_{\text {molar }}$ ratio of 170 (Table A2). On the one hand, these results confirm the presence of a relatively important concentration of Si coprecipitated and/or adsorbed to hydrobasaluminite ( $\mathrm{Si}$ is the third major component of these precipitates). On the other hand, they show how Si concentration in the precipitates is linked to the availability of dissolved $\mathrm{Si}$ in the AMD. Specifically, as $\mathrm{Si}$ concentration decreases in the waters from PP1 $\left(\mathrm{Al} / \mathrm{Si}_{\text {molar }}=2.7\right)$ to PP3 $\left(\mathrm{Al} / \mathrm{Si}_{\text {molar }}=0.5\right)$ it also decreases in the corresponding hydrobasaluminite. Notice that hydrobasaluminite and chalcedony are oversaturated in the waters of both sampling points (Fig. A3).

Finally, $\mathrm{Si}$ is also present in the aged Al-rich banded formations coating the surface of the creek boulders. These precipitates can be understood as a record of the precipitation history of Paradise Portal AMD. Nevertheless, $\mathrm{Si}$ concentrations and $\mathrm{Al} / \mathrm{S}_{\text {molar }}$ ratios of two different Al-rich layers within the banded formations show very similar values when compared with the fresh precipitates from this sampling point (Fig. 6 and Table A2).

Sánchez-España et al. $(2016,2018)$ suggested that the transformation of these Si and Fe-rich hydrobasaluminites could eventually lead to the formation of meta-stable proto-aluminosilicates leading to the final generation of other more stable aluminosilicates like clays (e.g., nontronite, kaolinite, halloysite, ...). Despite the fact that no aluminosilicate minerals were found during direct observation on the sediments at Paradise Portal, the results of the present study present the co-occurrence of $\mathrm{Si}$ and $\mathrm{Al}$ in the different stages of formation of hydrobasaluminite in this kind of system.

\subsection{Geochemical and mineralogical processes controlling metal mobility in AMD at mildly acidic $\mathrm{pH}$ (5 to 5.5)}

As previously stated, the hydrochemistry of the Paradise Portal system is controlled by hydrobasaluminite precipitation, buffering water $\mathrm{pH}$ around 5 to 5.5. This apparently simple aqueous system actually comprises a series of coupled geochemical and mineralogical processes controlling metal mobility. A conceptual model of the studied system is presented in Fig. 9. The three dominant geochemical processes are: 1) nanoparticle formation and size decrease along the creek, 2) hydrobasaluminite neoformation on the riverbed, and 3) precipitate accretion and accumulation on the riverbed. Please notice that processes 1 and 2 can only be attributed to summer time conditions (when the sampling was performed) and also that the presence of iron rich layers in the $\mathrm{Al}$ and $\mathrm{Fe}$ banded formations on the riverbed clearly records the existence of different hydrochemical environments during other seasons of the year. Also, it is important to acknowledge that the obtained results do not allow defining if hydrobasaluminite neoformation on the riverbed is the result of the aggregation and sedimentation of previous water suspended nano to microparticles, an independent growth from the surface of the boulders or a mixture of them both.

Metals are distributed between the aqueous (i.e., dissolved) and solid components (i.e., suspended particles, fresh precipitates and aged sediments) of the system. Concerning V and Ti transport, the first section of the system (PP1-PP2) is characterized by the presence of those metals, either dissolved or incorporated in the suspended particles; whereas in the second section (PP3-PP4) $\mathrm{V}$ and Ti are exclusively transported in the suspended particles.

Another important effect that was observed in the Paradise Portal system is the dramatic reduction in size of the hydrobasaluminite nanoparticles as a result of the sudden dilution of the original AMD effluent by an alpine creek (Table 1). This nanoparticles size reduction had no effect on $\mathrm{V}$ and $\mathrm{Ti}$ transport by the suspended particles.

A second predominant geochemical process is hydrobasaluminite neoformation and growth on the riverbed (Fig. 8), which cycles metals between the water and the sediments. Neoformed hydrobasaluminite scavenges a number of metals (Table A2), most importantly P, Th, W, V and Ti (Fig. 5). On the other hand, other elements such as Be, As, Se and Ba tended to remain in solution (Figs. 5 and 7). It is important to notice that previous studies at controlled laboratory conditions have shown that hydrobasaluminite has a great capacity to adsorb As (Carrero et al., 2017). However, this hydrobasaluminite and As affinity was not observed in the Paradise Portal natural system. On the contrary, As showed a tendency to remain in solution (Fig. 5).

A third stage of the minerals formed in the Paradise Portal system is the accretion and accumulation of precipitates on the riverbed (Fig. 9). The sedimentary record is tangible evidence of the variations experienced by the hydrochemical system through time. In this respect, the layers developed on the riverbed allow distinction between two different orders of hydrochemical variations: a) major events, and b) minor fluctuations (Fig. 9). The most abrupt hydrochemical change

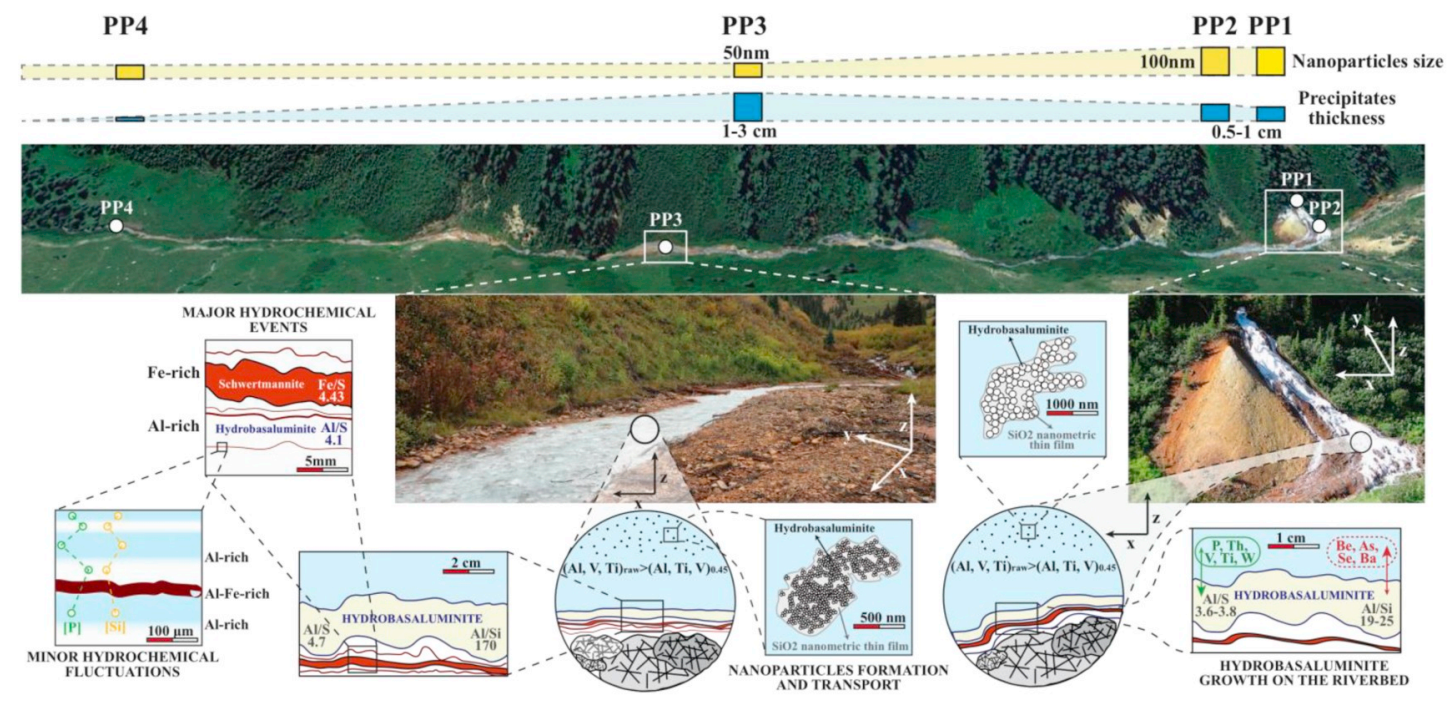

Fig. 9. Schematic representation of the various geochemical and mineralogical process observed in the Paradise Portal system. 
experienced by the system is the transition from an $\mathrm{Al}^{3+}$ to a $\mathrm{Fe}^{3+}$ controlled system. This changeover, although not observed in the waters of the system during several visits to the field site, is clearly recorded by the presence of Fe-rich layers at various depths in the sediments. This switch in the system can easily occur if the effluent waters emerge with a similar composition but an initial $\mathrm{pH}$ lower than 4.5. As shown by many previous studies (e.g. Caraballo et al., 2013 and references therein), the new hydrochemical conditions will most probably induce the precipitation of schwertmannite $\left(\mathrm{Fe}_{8} \mathrm{O}_{8}(\mathrm{OH})_{8-2 x}\left(\mathrm{SO}_{4}\right)_{x}\right.$, with $0.75<x<2.58$ ). This hypothesis is in agreement with the $\mathrm{Fe} /$ $S_{\text {molar }}$ ratio of 4.43 (within the range accepted for schwertmannite) found in a well-developed Fe-rich layer in the riverbed precipitates (Table A2 and Fig. 9) and with the results from the numerical simulations (Appendix A).

On the other hand, minor hydrochemical fluctuations were recorded in the form of subtle changes in the concentration of some sensitive elements. In this regard, detailed examination of the Al-rich layers revealed the existence of $\mu \mathrm{m}$-size bands of alternating Si and P composition with opposite trends (Figs. 6 and 7). Similar cyclic fluctuations have been previously attributed to seasonal changes in the water chemistry (Caraballo et al., 2011c).

\section{Conclusions}

The Paradise Portal geochemical system is simple (hydrobasaluminite is the predominant mineral phase precipitating) but at the same time elaborate because metals and metalloids transport and sink processes are controlled by suspended nanoparticles, neoformed fresh precipitates on the surface of the riverbed boulders and aged $\mathrm{Al}$ and $\mathrm{Fe}$ banded formations. After a characterization and description of the different sections of this geochemical system, the co-occurrence of $\mathrm{Al}$ and $\mathrm{Si}$ in the system precipitates was confirmed. On the one hand, suspended hydrobasaluminite nanoparticles were typically coated by a nanometric thin film of $\mathrm{SiO}_{2}$ (probably in the form of chalcedony). Simultaneously, a drastic reduction in size of the hydrobasaluminite nanoparticles (from $100 \mathrm{~nm}$ to $50 \mathrm{~nm}$ ) was observed as a result of the sudden dilution of the original AMD effluent by an alpine creek. On the other hand, fresh and aged precipitates of the riverbed are systematically made of hydrobasaluminite with significant amounts of $\mathrm{Si}(\mathrm{Al}$ / $\mathrm{Si}_{\text {molar }}$ ratios from 19.1 to 170 in the fresh precipitates). The sedimentary record in the $\mathrm{Al}$ (and $\mathrm{Fe}$ ) banded formations allowed the distinction between two different sets of hydrochemical conditions with time. The most abrupt hydrochemical change experienced by the system is the transition from an $\mathrm{Al}^{3+}$ to a $\mathrm{Fe}^{3+}$ controlled system (marked by a few Fe-rich layers between the most frequent Al-rich layers). Complementary, minor cyclic fluctuations were recorded in the form of $\mu \mathrm{m}$-size bands of alternating Si and P composition with opposite trends within the Al-rich layers. Both abrupt and minor changes in the sedimentary record are proposed to be the response of seasonal and interannual changes in the AMD chemistry. Concerning other metals and metalloids mobility, $\mathrm{P}, \mathrm{Th}, \mathrm{V}, \mathrm{W}, \mathrm{Ti}$ and $\mathrm{B}$ showed a tendency to be preferentially incorporated into hydrobasaluminite, while others like $\mathrm{Be}, \mathrm{As}, \mathrm{Se}$ or Ba tend to remain dissolved in the water.

Comparisons of the current study observations with other recent studies have shown some discrepancies in the interaction of hydrobasaluminite with $\mathrm{Si}$ and other metals and metalloids (e.g., As). Although no definitive reason for these disparities was determined, the current state of knowledge indicates that these adsorption/coprecipitation and mineral precipitation processes are extremely dependent on $\mathrm{pH}$ and element speciation. Future studies of similar environments will allow clarification of these discrepancies as well to build the bridge between $\mathrm{Si}$-rich hydrobasaluminite formation and a possible transition to meta-stable proto-aluminosilicates leading to the final generation of other more stable aluminosilicates.

\section{Acknowledgments}

This study was partially financed by the program Fondecyt Iniciación $\mathrm{N}^{\circ} 11150002$ and U-Inicia from the University of Chile. M.A.C. was financially supported by the Spanish Ministry of Education through the Post-doctoral International Mobility Subprogramme I+D $+i$ 2008-2011. M.A.C. gratefully acknowledges the support from the Advanced Mining Technology Center of the University of Chile. The authors thank M. Cabañas and R. Bartrolí (IDAEA-CSIC), Chris Winkler and Stephen McCartney (NanoEarth-NCFL), Cristobal Cantero (Servicios Centrales I+ D-UHU) for their analytical assistance. RBW and PLV were supported by the Mineral Resources Program of the U.S. Geological Survey. Any use of trade, firm, or product names is for descriptive purposes only and does not imply endorsement of the U.S. Government. We would also like to thank Dr. Karen Johannesson (Editor) and two anonymous reviewers for their suggestions and comments that significantly improved the quality of the original manuscript.

\section{Appendix A. Supplementary data}

Supplementary data associated with this article can be found in the online version, at doi:0.1016/j.chemgeo.2019.04.013. These data include the Google map of the most important areas described in this article.

\section{References}

Ayora, C., Caraballo, M.A., Macias, F., Rötting, T.S., Carrera, J., Nieto, J.M., 2013. Acid mine drainage in the Iberian Pyrite Belt: 2. Lessons learned from recent passive remediation experiences. Environ. Sci. Pollut. Res. 20, 7837-7853.

Ayora, C., Macías, F., Torres, E., Lozano, A., Carrero, S., Nieto, J.M., Pérez-López, R., Fernández-Martínez, A., Castillo-Michel, H., 2016. Recovery of rare earth elements and yttrium from passive-remediation systems of acid mine drainage. Environ. Sci. Technol. 50, 8255-8262. https://doi.org/10.1021/acs.est.6b02084.

Ball, J.W., Nordstrom, D.K., 1991. User's manual for WATEQ4F, with revised thermodynamic data base and test cases for calculating speciation of major, trace, and redox elements in natural waters. In: U.S. Geological Survey Open-File Report 91-183, (189 pp.).

Barnard, A.S., Guo, H., 2012. Nature's Nanostructures. Pan Stanford Publishing Pte. Ltd., USA, pp. 604.

Barrón, V., Torrent, J., 2013. Iron, Manganese and Aluminum Oxides and Oxyhydroxides. European Mineralogical Union Notes in Mineralogy 14. Chapter 9. pp. 297-336.

Bigham, J.M., Nordstrom, D.K., 2000. Iron and Aluminum Hydroxysulfates from Acid Sulfate Waters. Rev. Mineral. Geochem. 40, 351-403. https://doi.org/10.2138/rmg. 2000.40.7.

Bigham, J.M., Schwertmann, U., Traina, S.J., Winland, R.L., Wolf, M., 1996. Schwertmannite and the chemical modeling of iron in acid sulfate waters. Geochim. Cosmochim. Acta 60, 2111-2121.

Brown Jr., G.E., Calas, G., 2011. Environmental mineralogy - Understanding element behavior in ecosystems. Compt. Rendus Geosci. 343, 90-112.

Caraballo, M.A., Macías, F., Nieto, J.M., Castillo, J.C., Quispe, D.L., Ayora, C., 2011a. Hydrochemical performance and mineralogical evolution of a dispersed alkaline substrate (DAS) remediating the highly polluted acid mine drainage in the full-scale passive treatment of Mina Esperanza (SW Spain). Am. Mineral. 96, 1270-1277.

Caraballo, M.A., Macías, F., Rötting, T.S., Nieto, J.M., Ayora, C., 2011b. Long term remediation of highly polluted acid mine drainage: a sustainable approach to restore the environmental quality of the Odiel River basin. Environ. Pollut. 159, 3613-3619.

Caraballo, M.A., Sarmiento, A.M., Sanchez-Rodas, D., Nieto, J.M., Parviainen, A., 2011c. Seasonal variations in the formation of $\mathrm{Al}$ and $\mathrm{Si}$ rich Fe-stromatolites in the highly polluted acid mine drainage of Agua Agria Creek (Tharsis, SW Spain). Chem. Geol. 284, 97-104.

Caraballo, M.A., Rimstidt, J.D., Macías, F., Nieto, J.M., Hochella Jr., M.F., 2013. Metastability, nanocrystallinity and pseudo-solid solution effects on the understanding of schwertmannite solubility. Chem. Geol. 360-361, 22-31.

Caraballo, M.A., Michel, F.M., Hochella Jr., M.F., 2015. The rapid expansion of environmental mineralogy in unconventional ways: beyond the accepted definition of a mineral, the latest technology, and using nature as our guide. Am. Mineral. 100, 14-25.

Carrero, S., Pérez-López, R., Fernández-Martínez, A., Cruz-Hernández, P., Ayora, C., Poulain, A., 2015. The potential role of aluminium hydroxysulphates in the removal of contaminants in acid mine drainage. Chem. Geol. 417, 414-423.

Carrero, S., Fernández-Martínez, A., Pérez-López, R., Poulain, A., Salas-Colera, E., Nieto, J.M., 2017. Arsenate and selenate scavenging by basaluminite: insights into the reactivity of aluminum phases in acid mine drainage. Environ. Sci. Technol. 51, 28-37.

Casey, W.H., Rustad, J.R., Spiccia, R., 2009. Minerals as molecules-use of aqueous oxide and hydroxide clusters to understand geochemical reactions. Chem. Eur. J. 15, 
4496-4515.

Cory, N., Buffam, I., Laudon, H., Bishop, K., 2006. Landscape control of stream water aluminum in a boreal catchment during spring flood. Environ. Sci. Technol. 40, 3494-3500.

Ehlmann, B.L., Swayze, G.A., Milliken, R.E., Mustard, J.F., Clark, R.N., Murchie, S.C., Breit, G.N., Wray, J.J., Gondet, B., Poulet, F., Carter, J., Calvin, W.M., Benzel, W.M. Seelos, K.D., 2016. Discovery of alunite in Cross crater, Terra Sirenum, Mars: evidence for acidic, sulfurous waters. Am. Minerol. 101, 1527-1542.

Farrand, W.H., Glotch, T.D., Rice Jr., J.W., Hurowitz, J.A., Swayze, G.A., 2009. Discovery of jarosite within the Mawrth Vallis region of Mars: implications for the geologic history of the region. Icarus 204, 478-488.

Furrer, G., Phillips, B.L., Ulrich, K., Pöthig, R., Casey, W.H., 2002. The origin of aluminum flocs in polluted streams. Science 297, 2245-2247.

Gammons, C.H., Nimick, D.A., Parker, S.R., 2015. Diel cycling of trace elements in streams draining mineralized areas—a review. Appl. Geochem. 57, 35-44.

Gimeno, M.J., Auque, L.F., Nordstrom, D.K., 2000. REE speciation in low-temperature acidic waters and the competitive effects of aluminum. Chem. Geol. 165, 167-180.

Heinzel, E., Janneck, E., Golmbitza, F., Schlömann, M., Seifert, J., 2009. Population dynamics of iron-oxidizing communities in pilot plants for the treatment of acid mine waters. Environ. Sci. Technol. 43, 6138-6144.

Hicks, W.S., Bowman, G.M., Fitzpatrick, R.W., 2009. Effect of season and landscape position on the aluminum geochemistry of tropical acid sulfate soil leachate. Aust. J. Soil Res. 47, 137-153.

Hochella Jr., M.F., Lower, S.K., Maurice, P.A., Penn, R.L., Sahai, N., Sparks, D.L., Twining, B.S., 2008. Nanominerals, mineral nanoparticles, and Earth systems. Science 319, 1631-1635.

Johnson, J., Oelkers, E., Helgeson, H., 1992. SUPCRT92: a software package for calculating the standard molal thermodynamic properties of minerals, gases, aqueous species and reactions from 1 to 5000 bar and 0 to $1000^{\circ} \mathrm{C}$. Comput. Geosci. 18, 899-947.

Johnson, C.A., Freyer, G., Fabisch, M., Caraballo, M.A., Kusel, K., Hochella Jr., M.F., 2014. Observations and assessment of iron oxide and green rust nanoparticles in metal-polluted mine drainage within a steep redox gradient. Environ. Chem. 11, 377-391.

Jones, A.M., Collins, R.N., Waite, T.D., 2011. Mineral species control of aluminum solubility in sulfate-rich acidic waters. Geochim. Cosmochim. Acta 75, 965-977.

Larsen, E.S., Cross, W., 1956. Geology and Petrology of the San Juan region Southwestern Colorado. In: USGS Prof. Paper 258, (303 pp.).

Lükewille, A., Van Breemen, N., 1991. Aluminum precipitates from groundwater of an aquifer affected by acid atmospheric deposition in the Senne, Northern Germany. Water Air Soil Pollut. 63, 411-416.

Macías, F., Caraballo, M.A., Rötting, T.S., Pérez-López, R., Nieto, J.M., Ayora, C., 2012 From highly polluted $\mathrm{Zn}$-rich acid mine drainage to non-metallic waters:
Implementation of a multi-step alkaline passive treatment system to remediate metal pollution. Sci. Total Environ. 433, 323-330.

Majzlan, J., 2011. Thermodynamic stabilization of hydrous ferric oxide by adsorption of phosphate and arsenate. Environ. Sci. Technol. 45, 4726-4732.

McKnight, D.M., Duren, S.M., 2004. Biogeochemical processes controlling midday ferrous iron maxima in stream waters affected by acid rock drainage. Appl. Geochem. 19, 1075-1084.

Munk, L., Faure, G., Pride, D.E., Bigham, J.M., 2002. Sorption of trace metals to an aluminum precipitate in a stream receiving acid rock-drainage: Snake River, Summit County, Colorado. Appl. Geochem. 17, 421-430.

Parkhurst, D.L., Appelo, C.A.J., 2013. Description of input and examples for PHREEQC version 3.4-a computer program for speciation, batch-reaction, one-dimensional transport, and inverse geochemical calculations. In: U.S. Geological Survey Techniques and Methods, book 6, chap. A43, pp. 497.

Railsback, L.B., 2003. An earth scientist's periodic table of the elements and their ions. Geology 31, 737-740.

Sánchez-España, J., López Pamo, E., Pastor, Santofimia, E., Reyes Andrés, J., Martín Rubí, J.A., 2006. The removal of dissolved precipitates during oxidation and neutralization of acid mine waters, Iberian Pyrite Belt. Aquat. Geochem. 12, 269-298.

Sánchez-España, J., Yusta, I., Diez-Ercilla, M., 2011. Schwertmannite and hydrobasaluminite: a re-evaluation of their solubility and control on the iron and aluminium concentration in acidic pit lakes. Appl. Geochem. 26, 1752-1774.

Sánchez-España, J., Yusta, I., Burgos, W.D., 2016. Geochemistry of dissolved aluminum at low $\mathrm{pH}$ : hydrobasaluminite formation and interaction with trace metals, silica and microbial cells under anoxic conditions. Chem. Geol. 441, 124-137. https://doi.org/ 10.1016/j.chemgeo.2016.08.004.

Sánchez-España, J., Wang, K., Falagán, C., Yusta, I., Burgos, W.D., 2018. Microbially mediated aluminosilicate formation in acidic anaerobic environments: a cell-scale chemical perspective. Geobiology 16, 88-103.

Väänänen, M., Kupiainen, L., Rämö, J., Sarpola, A., Tanskanen, J., 2012. Speciation and coagulation performance of novel coagulant - Aluminium formate. Sep. Purif. Technol. 86, 242-247.

Verplanck, P.L., Nordstrom, D.K., Taylor, H.E., Kimball, B.A., 2004. Rare earth element partitioning between hydrous ferric oxides and acid mine water during iron oxidation. Appl. Geochem. 19, 1339-1354.

Wanner, C., Pöthig, R., Carrero, S., Fernandez-Martinez, A., Jäger, C., Furrer, G., 2018. Natural occurrence of nanocrystalline Al-hydroxysulfates: insights on formation, $\mathrm{Al}$ solubility control and As retention. Geochim. Cosmochim. Acta 238, 252-269.

Weber, K.A., Achenbach, L.A., Coates, J.D., 2006. Microorganisms pumping iron: anaerobic microbial iron oxidation and reduction. Nat. Rev. Microbiol. 4, 752-764.

Webster, J.G., Swedlund, P.J., Webster, K.S., 1998. Trace metal adsorption onto an acid mine drainage iron(III) oxyhydroxy sulfate. Environ. Sci. Technol. 32, 1361-1368. 